\title{
Aktywność turystyczna podkarpackiej młodzieży jako źródło wspomagania jej rozwoju osobowego
}

\author{
The Tourist Activity of Youth in Podkarpackie \\ region as a Resource Supporting \\ Their Personal Growth
}

\begin{abstract}
ABSTRAKT
Turystyka należy do tych form aktywności ludzkiej, które maja szczególne znaczenie dla rozwoju osobowości, samokształcenia i przygotowania człowieka do pełnienia różnorodnych społecznych ról, funkcji i zadań. Jak żadna inna sfera działalności, daje szansę integracji wpływów wychowawczych rodziny, szkoły, pozaszkolnych instytucji wychowawczych oraz nieformalnych grup rówieśniczych, a także, co szczególnie ważne, samodzielnej akływności jej uczestników. Uczestnictwo w turystyce rozumiane jest coraz częściej jako edukacja dla rozwoju psychofizycznego i kulturowego jednostki, jako edukacja do kształtowania potrzeb zmiany osobistego życia z biernego na aktywny, twórczy, samorealizacyiny, z wpisanym dobrostanem zdrowia fizycznego, psychicznego i społecznego w rozwoju każdej jednostki. $\mathrm{Na}$ ten walor aktywności turystycznej wskazuje wielu badaczy. Literatura przedmiotu ukazuje i dowodzi, że istnieje wiele zwiqzków uprawiania turystyki, szczególnie przez dzieci i młodzież, z ich rozwojem psychofizycznym.

SLOWA KLUCZOWE wychowanie, wspomaganie rozwoju, aktywność turystyczna, młodzież, Podkarpacie

KEYWORDS

upbringing, support the growth, tourist activity, youth, Podkarpackie region

SPI Vol. 20, 2017/2

ISSN 2450-5358

e-ISSN 2450-5366

DOI: 10.12775/SPI.2017.2.010

Raporty z badań
\end{abstract}


Na potrzeby niniejszego opracowania postanowiono zdiagnozować, czy aktywność turystyczna jest dla podkarpackiej młodzieży szkół ponadgimnazjalnych źródłem i sposobem samodoskonalenia. Starano się m.in. znaleźć odpowiedzi na następujqce pytania: czy badana młodzież dostrzega korzyści wynikajqce z uprawiania turystyki, zarówno dla rozwoju mentalnego, jak i fizycznego własnego organizmu (jeśli tak, to jakie), czy wyjazdy turystyczne wpłynęły na rozwój wiedzy i umiejętności, czy turystyka może być sposobem przeciwdziałania złym zachowaniom, które sq spotykane wśród młodzieży w jej codziennym życiu (w czasie wolnym)?

\section{ABSTRACT}

Tourism is one of the forms of human activity which has special importance for the progress of personality, self-education and preparing man for performing a variety of social roles, functions and duties. Tourism, like any other sphere of activity, provides the chance to integrate the educational influences of the family, school, non-school educational institutions, and informal peer group, and, most importantly, self-activity of the participants. Participation in tourism is more and more often understood as education for the mental, physical and cultural progress of man, education for the evolution of the needs in personal life from the passive to an active, creative, self-realization, with the physical, mental and social welfare of everyone taken into account.

This value of tourist activity has been indicated by many researchers as can be seen in the literature of the subject which details number of associations, especially for children and young people, which have an impact on their physical and psychological development.

For the purposes of this study, it was decided to diagnose whether tourist activity is a resource and a way to improve themselves for young people in secondary schools in the Podkarpackie region. Efforts were made to find answers to the following questions: Do young people see the benefits of tourism, both for their mental and physical development? Should tourist trips affect the evolution of their knowledge and skills? Can tourism be a way to prevent the bad behavior which is common among young people in their daily lives (during their free time)? 


\section{Wprowadzenie: Wspomaganie rozwoju młodzieży a kierowanie własnym rozwojem}

W wielu definicjach wychowania akcentuje się obecnie, że powinno być ono wspomaganiem młodych ludzi w ich naturalnym i spontanicznym rozwoju. Zgodnie z tym założeniem, wychować oznacza wyzwalać, dodawać odwagi, uwalniać od ubezwłasnowolnienia, usuwać wpływy zagrażające naturalnemu i spontanicznemu rozwojowi dzieci i młodzieży. Należy przygotowywać ich do przyszłego życia przez mobilizację do własnej aktywności, pobudzać do zachowań zgodnych z oczekiwaniami społecznymi, zasadami moralności, a także etyki normatywnej. W rozumianym w ten sposób wychowaniu podkreśla się doniosłe znaczenie współdziałania i współpracy między wychowawcą i wychowankiem, a przede wszystkim rolę wzajemnego ich porozumiewania się $\mathrm{w}$ warunkach autentycznego partnerstwa i demokratyzmu ${ }^{1}$.

Rozwój to zdaniem Marii Kielar-Turskiej „długotrwały proces względnie nieodwracalnych zmian o charakterze ilościowym i jakościowym; zasadniczo ukierunkowany progresywnie, dotyczący różnych sfer rozwijającego się podmiotu, cechujący się indywidualnym tempem i rytmem, zależny od wielu uwarunkowań biologicznych, środowiskowych oraz od aktywności własnej podmiotu"2. Natomiast wspomaganiem nazywamy proces intencjonalnych lub nieintencjonalnych oddziaływań człowieka na człowieka. Występują one w różnych formach i prowadzą do: potęgowania dobrostanu, powstrzymywania czynników zagrażających dobrostanowi, poprawiania, usuwania nieprawidłowości lub przywracania utraconego dobrostanu jednostki, co pozwala jej na samodzielne i odpowiednie do jej możliwości rozwiązywanie problemów życiowych. Proces ten wiąże się $z$ ingerencją bądź to w biologiczne funkcjonowanie organizmu, bądź w organizację doświadczeń życiowych i psychologiczne mechanizmy sterujące postępowaniem człowieka (obraz świata, postawy, motywacja, obraz własnej osoby) albo też w kulturowy system znaczeń

1 Por. M. Łobocki, $A B C$ wychowania, Lublin 2003, s. 12.

2 M. Kielar-Turska, Analiza pola semantycznego terminórw zwiquanych ze wspomaganiem rozwoju, w: Wspomaganie rozwoju. Psychostymulacja i psychokorekcja, t. 5, red. B. Kaja, Bydgoszcz 2003, s. 13. 
(system norm i wartości). Proces wspomagania jest wspomaganiem rozwoju wówczas, jeśli uwzględnia istotne cechy zmian rozwojowych: ich względną trwałość i miejsce w sekwencji procesów rozwojowych na poszczególnych etapach rozwoju ${ }^{3}$.

Ciekawy model wspomagania rozwoju zaproponowała Barbara Kaja. Składa się on z następujących elementów: 1) wspomagający jest co najwyżej moderatorem wnikającym w rozumienie świata wartości osoby wspomaganej; 2) osoby wspomaganej nie traktuje się a priori jako mniej kompetentnej, a stosowane metody dostosowane są do jej kompetencji i potrzeb; 3) preferuje się dyskurs jako element spotkania, a unika się numerycznego pouczania; 4) zakłada się otwartość na modyfikację programu wspomagania w zależności od sposobu, w jaki osoba przyjmuje lub odrzuca proponowane jej metody wywierania wpływu; 5) wspomaganie rozwoju ukierunkowane jest na zrozumienie człowieka, jego wartości, umożliwiające dyferencjację spraw ważnych od nieważnych, błahych od istotnych dla jego rozwoju i życia $\mathrm{w}$ świecie $\mathrm{z}$ poczuciem jego sensu; 6) osoba wspomagająca czuje się odpowiedzialna za osobę wspomaganą. Jest to zatem model wspomagania rozwoju oparty na wspólnym doświadczeniu ${ }^{4}$.

Ważną kwestią dotyczącą procesu wspomagania rozwoju jest zdaniem M. Kielar-Turskiej ustalenie kogo należy wspomagać. Autorka zauważa, że wspomaganie dotyczy nie tylko grup osób z zaburzeniami czy opóźnieniami rozwoju, czy też osób po urazach. Wspomagać należy również osoby, które dążą do lepszych osiągnięć. Ciekawą kwestią poruszaną przez tę uczoną jest ustalenie w jaki sposób należy wspomagać. Autorka wymienia dwie drogi. Po pierwsze, można wspomagać rozwój poprzez maksymalizowanie kompetencji moralnych jednostki i organizowanie sytuacji aktywizujących je oraz intensyfikowanie poczucia odpowiedzialności za drugiego człowieka. Drugim sposobem jest wzbudzenie wewnętrznego przeżywania wartości ${ }^{5}$.

Źródłem optymalnej aktywności człowieka jest więc wolne, odpowiedzialne, mądre i samodzielne, własne postępowanie,

3 Por. tamże, s. 20.

4 Por. B. Kaja, Wspomaganie rozwoju, czyli „dobrze jest mieć przyjaciót we wszystkich okolicznościach życia”, w: Wspomaganie rozwoju. Psychostymulacja i psychokorekcja, t. 6, red. B. Kaja, Bydgoszcz 2004, s. 21.

5 Por. M. Kielar-Turska, Analiza pola semantycznego terminów zwiqzanych ze wspomaganiem rozwoju, dz. cyt., s. 20-12. 
zorientowane na świadomie wybrane, zaakceptowane i realizowane wartości. Mądrych wyborów możemy natomiast dokonywać w klimacie zapewniającym uczestnikom procesu kształcenia i wychowania podmiotowe, partnerskie traktowanie, gwarantujące im poczucie bezpieczeństwa, wzajemną akceptację, współpracę i pomoc ${ }^{6}$.

Właściwości te immanentnie wpisują się w potrzeby młodzieży, która swe relacje ze światem pragnie porządkować w klimacie partnerstwa, wymaga też uwzględnienia jej potencjałów i zdolności. Relacje te powinny ewoluować w kierunku współpracy, integracji i działania animacyjnego. Konieczne jest tu działanie wspierające samokształcenie i samopomoc w rozwoju przez nierepresyjne towarzyszenie i monitorowanie dążeń autokreacyjnych młodzieży ${ }^{7}$. W okresie dorastania bowiem, na co zwrócił uwagę Andrzej J. Sowiński, rolą wychowawcy powinno być jedynie stymulowanie i kierowanie samowychowaniem, ponieważ na tym etapie jednostka podejmuje już samodzielną działalność kierowania własnym rozwojem. Wychowawca powinien wzmacniać, wspierać, stymulować oraz kierunkować aktywność samowychowawczą młodzieży. Najważniejszym zadaniem jest przekazanie młodzieży odpowiedniego systemu wartości moralnych, a nade wszystko przyswojenie ich przez wychowanków, co w przyszłości spowoduje samodzielną pracę nad sobą bez udziału wychowawcy ${ }^{8}$.

Zdaniem Mariana Nowaka, najważniejszym celem wychowania jest uzdalnianie podmiotu (wychowanka) do przejęcia kierownictwa nad własnym procesem rozwoju. Chodzi o takie ujmowanie wychowania, które zbliża je do procesu tzw. majeutyki osoby, czyli wzbudzenia osoby w wychowanku'.

Kierowanie własnym rozwojem to wszelkie świadome decyzje i poczynania danego człowieka, które przyczyniają się do korzystniejszego ukształtowania jego osobowości, drogi życiowej, dorobku,

6 Por. K. Denek, Wartości jako źródto edukacji, w: Dziecko w świecie wartości, t. 1, red. K. Denek i in., Kraków 2003, s. 30.

7 Por. E. Wysocka, Doświadczanie życia w mtodości-problemy, kryzysy i strategie ich rozwiazywania. Próba opisu strukturalno-funkcjonalnego modelu życia preferowanego przez mtodzież z perspektywy pedagogiki spotecznej, Katowice 2010, s. 457 .

8 Por. B. Alejziak, Samowychowanie a turystyka, Kraków 2008, s. 14.

9 Por. M. Nowak, Personalistyczne wychowanie, w: Encyklopedia pedagogiczna XXI wieku, t. 4, red. T. Pilch, Warszawa 2005, s. 357. 
kariery. Wchodzą tu w grę zarówno oddziaływania cząstkowe, jak i wielostronne, takie których efekty są drobne, jak i poczynania brzemienne w skutki. Może się to sprowadzać do zwalczania jakichś wad, polegać na kształceniu zdolności albo dążeniu do wyrobienia w sobie nowych cech charakteru. Ma miejsce i wówczas, gdy podejmujemy jakieś trudne zadanie, które powiększa nasze doświadczenie, otwiera nowe horyzonty i możliwości, prowadzi do spotkania z ludźmi. Głównymi elementami będącymi składowymi pojęcia „kierowanie własnym rozwojem” są, według Zbigniewa Pietrasińskiego, „samokształcenie” $i$ „samowychowanie”, noszące miano "pracy nad sobą" ${ }^{10}$.

Maria Dudzikowa określiła pracę nad sobą, zawierającą samokształcenie i samowychowanie, jako „samokształtowanie”. Rozumie przez nie inicjowanie i realizowanie przez jednostkę zadań w celu osiągania we własnej osobowości i zachowaniach zmian zgodnych z pożądanymi przez tę jednostkę standardami. Jednocześnie ta sama uczona wyróżniła następujące cechy pracy nad sobą: 1) utożsamiana jest ona $\mathrm{z}$ określonym rodzajem aktywności ludzkiej: wewnętrznej i zewnętrznej; 2) jednostka podejmująca tę aktywność posiada określony stopień dojrzałości psychofizycznej i społeczno-moralnej; 3) charakter, przejawy, natężenie tej aktywności wiążą się w różnym stopniu z socjalizacją i warunkami społecznymi, w których żyje jednostka; 4) cele tej aktywności wiążą się z koncepcjami, planami życia jednostki; 5) aktywności tej przypisuje się różny stopień świadomości, dobrowolności, samodzielności; 6) aktywność tę rozpatruje się zasadniczo w kategoriach procesu, a więc jako ciąg logicznie powiązanych ze sobą czynności, mających na celu wprowadzenie przez jednostkę zmian we własnej osobowości; 7) proces ten zachodzi, gdy: a) jednostka odczuwa $w$ dużym stopniu niezadowolenie $z$ siebie, „zaniepokojenie” sobą, i doświadcza chęci dokonania w sobie samej zmian zgodnie z przyjętym przez siebie wzorem; b) jednostka wie, w jaki sposób może dokonywać zmian w sobie samej ${ }^{11}$.

Zagadnienie pracy nad sobą, inaczej zwanej „autokreacją”, przedstawił Heliodor Muszyński w postaci cyklu przedsięwzięć samowychowawczych, stanowiących zwartą koncepcję procesu

10 Por. Z. Pietrasiński, Kierowanie wtasnym rozwojem, Warszawa 1977, s. 8-9.

11 Por. M. Dudzikowa, Praca mtodzieży nad sobą. Z teorii i praktyki, Warszawa 1993, s. 16. 
samowychowania. Wyróżnił następujące ogniwa tego cyklu: 1) idealizacja; 2) samopoznanie; 3) samoocena wstępna; 4) aspiracje perfekcjonistyczne; 5) decyzje samorealizacyjne; 6) działania samowychowawcze; 7) samoocena końcowa ${ }^{12}$.

Każdy wychowanek potrzebuje zatem określonego systemu norm i zasad postępowania, zwanych wartościami. Tego typu normy i zasady sprzyjają jego rozwojowi, a jednocześnie chronią go przed błędnymi postawami. Nie mniej oczywista jest potrzeba wychowania w sferze wartości, czyli pomaganie wychowankom, by odkryli i respektowali podstawowe wartości. Nie jest to bowiem ani łatwy, ani spontaniczny proces ${ }^{13}$.

Życzliwe i mądre wsparcie wychowawcze, ukierunkowane na rozwój i wzmacnianie własnego ,ja” adolescenta, poprzez umożliwienie mu różnych form aktywności w pozytywnym wychowawczo życiu środowiska rówieśniczego i szerszego środowiska społecznego, prowadzi do wzrostu wiary we własne siły i możliwości. Wpływa na podniesienie samooceny, umożliwia wzrost kontroli wewnętrznej, prowadzi do samosterowności ${ }^{14}$.

Pozytywny stosunek do siebie, do własnego ,ja” we wszystkich jego aspektach, jest - jak zauważył Henryk Kulas - prawdopodobnie najważniejszą determinantą pomyślnego przystosowania jednostki do otoczenia, warunkiem zadowolenia $\mathrm{z}$ samego siebie i poczucia osobistego szczęścia. Samoocena wpływa na myślenie, motywację i zachowanie jednostki, a także na sposób percepcji swoich przyjaciól, rodziny, na przyszłe plany życiowe oraz na wartościowanie życia. Jest wskaźnikiem naszego życia uczuciowego, odzwierciedleniem różnorodnych nastrojów, stanów radości i zadowolenia bądź niepokoju i przykrych przeżyć. Wpływ samooceny na postępowanie jednostki wyraża się, najogólniej rzecz biorąc, w tym, że reguluje ona zachowanie człowieka w taki sposób, aby było ono zgodne z tym, co jednostka sama o sobie sądzi. Może być źródłem motywacji do podjęcia pracy nad sobą, dążenia jednostki do modyfikacji, poprawy posiadanych cech. Dzięki temu samoocena stanowi istotny czynnik

12 Por. A. Ratusiowa, Autokreacja charakterologiczna, w: Encyklopedia pedagogiczna XXI wieku, t. 1, red. T. Pilch, Warszawa 2003, s. 243.

13 Por. M. Dziewiecki, Osoba i wychowanie. Pedagogika personalistyczna w praktyce, Kraków 2003, s. 154.

14 Por. A. Ratusiowa, Autokreacja charakterologiczna, dz. cyt., s. 240. 
osobotwórczy, bodziec do doskonalenia wewnętrznego człowieka, źródło samowychowania ${ }^{15}$.

Zatem wychowanie człowieka powinno się rozumieć jako przygotowanie i wprowadzenie go do samowychowania. Samowychowanie jest samokształceniem, formowaniem własnego osobowego ,ja”. Dzięki samowychowaniu wychowanek nie jest bierny, sugerowane treści, wartości, motywy nie przyjmuje mechanicznie, ale wewnętrznie rozumie, akceptuje i postępuje zgodnie $\mathrm{z}$ nimi. $\mathrm{W}$ wychowaniu można mówić o rozwoju wychowanka, gdy ciągle rozszerza się sfera jego samodzielności. Młody człowiek powinien realnie zobaczyć swoje możliwości, umiejętności, talenty, a także braki, słabości, sposób przeżywania świata. Dokonuje samooceny i tworzy obraz samego siebie. Rola zgodnego obrazu samego siebie $\mathrm{z}$ rzeczywistością jest doniosła w doskonaleniu się przez pracę nad sobą. Jak zauważyła Bożena Alejziak, trudno rozdzielić samowychowanie od wychowania, ponieważ oba procesy łączą wielorakie powiązania. Można jednak przyjąć, że w okresie przedszkolnym i wczesnoszkolnym częściej należy mówić o wychowaniu, natomiast $\mathrm{w}$ okresie dorastania i dorosłym życiu jednostki częściej o samowychowaniu ${ }^{16}$.

\section{Koncepcje procesu wspomagania rozwoju młodzieży przez turystykę}

Turystyka należy do tych form aktywności ludzkiej, które mają szczególne znaczenie dla rozwoju osobowości, samokształcenia człowieka i przygotowania go do pełnienia różnorodnych społecznych ról, funkcji i zadań ${ }^{17}$.

Jan Pięta dokonał ciekawej analizy pracy nad sobą jako funkcji czasu wolego. $Z$ jego obserwacji wynika, że podejmowana z zainteresowania i zamiłowania praca nad sobą charakteryzuje się niejednokrotnie wysiłkiem i wyrzeczeniem oraz może być związana z podjęciem odpowiedzialnego zadania. $\mathrm{W}$ takim przypadku ma ogromne znacznie wychowawcze. Dlatego podejmowane w czasie wolnym

15 Por. H. Kulas, Samoocena mtodzieży, Warszawa 1986, s. 32-46.

16 Por. B. Alejziak, Samowychowanie a turystyka, dz. cyt., s. 14.

17 Por. L. Turos, Wprowadzenie do wiedzy o turystyce edukacyjnej, wyd. 2. rozszerzone, Warszawa 2001, s. 17. 
zajęcia kształcące stanowią wydatną pomoc w rozwoju osobowości oraz $\mathrm{w}$ doskonaleniu się w wybranej dziedzinie wiedzy, sztuki, techniki, życia społecznego i kultury fizycznej. Jednocześnie autor dokonał analizy wybranych czynności wolnoczasowych pod kątem możliwości ich wykorzystania na potrzeby pracy nad sobą. Do czynności o stuprocentowym i znacznym wpływie zaliczył: samokształcenie, turystykę, sport, amatorstwo artystyczne, majsterkowanie i amatorstwo techniczne. Znaczny udział elementów pracy nad sobą dostrzegł w turystyce poznawczej i kwalifikowanej. W pierwszym bowiem przypadku mamy do czynienia $\mathrm{z}$ kształceniem i wychowaniem, w drugim - z pracą nad doskonaleniem własnej sprawności fizycznej i utrzymaniem dobrego stanu zdrowia ${ }^{18}$.

W polskiej literaturze turystycznej możemy znaleźć wiele koncepcji wspomagania rozwoju młodzieży poprzez uprawianie turystyki. Na ten walor aktywności turystycznej wskazuje wielu badaczy tego zjawiska. Wśród najważniejszych koncepcji należy wskazać tu koncepcje wychowawczych funkcji turystyki prezentowane przez Krzysztofa Przecławskiego, Kazimierza Denka, Lucjana Turosa, Tadeusza Łobożewicza, Grzegorza Bieńczyka, Wiesława Siwińskiego, Krzysztofa Lubańskiego i innych. W swoich pracach ci najwybitniejsi przedstawiciele pedagogiki turystyki ukazują i dowodzą, że istnieje wielu związków między uprawianiem turystyki, szczególnie przez dzieci i młodzież, a jej wpływem na ich rozwój psychofizyczny.

Zdaniem T. Łobożewicza, turystyka jest tą formą aktywności ruchowej, w której istnieją optymalne warunki do łączenia pracy nad rozwojem psychicznym i fizycznym człowieka z działalnością poznawczą, wychowawczą i kulturalną. Jest to zdaniem autora jedna z najważniejszych form ludzkiej aktywności ${ }^{19}$.

Możliwości tkwiące w aktywności turystycznej, mające doniosły wpływ na rozwój młodych ludzi, widoczne są w opisanych właśnie przez T. Łobożewicza i G. Bieńczyka rolach, jakie przypisuje się turystyce: 1) zaspokaja ona i kształtuje potrzeby poznawcze; 2) sprzyja rozwojowi zainteresowań, zamiłowań i uzdolnień; 3) jest elementem oświaty, pracy dydaktyczno-wychowawczej, integralnym elementem systemu edukacji narodowej; 4) kształci umiejętność obserwacji; 5) jest formą

18 Por. J. Pięta, Pedagogika czasu wolnego, Warszawa 2004, s. 54-57.

19 Por. L. Turos, Wprowadzenie do wiedzy o turystyce edukacyjnej, dz. cyt., s. 93. 
zdobywania nowych umiejętności i nawyków; 6) kształtuje naukowy pogląd na świat; 7) jest składnikiem kształcenia politechnicznego; 8) wzbogaca wiadomości i umiejętności; 9) rozbudza nawyki samokształcenia; 10) wiąże naukę szkolną z życiem; 11) ułatwia świadome i aktywne zdobywanie wiedzy; 12) umożliwia międzyprzedmiotową korelację wiedzy; 13) sprzyja operatywno-poglądowemu kształceniu; 14) spełnia postulat wielostronnego nauczania i uczenia się; 15) jest sposobem poglądowego nauczania; 16) stanowi skuteczny sposób odwerbalizowania i odformalizowania procesu nauczania; 17) uczy samodzielnego i racjonalnego myślenia i krytycyzmu ${ }^{20}$.

Z kolei K. Denek opracował typologię postaw, które kształtują uczestnictwo w turystyce. Zdaniem autora, wycieczki szkolne szczególnie intensywnie rozwijają postawy wobec przyrody i kultury oraz personalne (zwłaszcza postawy samokrytycyzmu, wiary we własne siły i autoafirmację). Zaspokajają potrzebę dociekliwości poznawczej $\mathrm{i}$ autoweryfikacji, a także turystycznej samorealizacji ${ }^{21}$.

W tym miejscu przedstawiona zostanie koncepcja wykorzystująca aktywność turystyczną dla potrzeb wspomagania rozwoju młodzieży oraz kierowania przez nią rozwojem własnym. Jest to koncepcja samokształcenia i samowychowania przez turystykę. Rozumiana jest ona jako „świadomie dokonany wybór takiej formy spędzania czasu wolnego (turystycznego) oraz świadome wykorzystanie jej dla samodzielnego kierowania własnym rozwojem"22. Twórcą tej koncepcji jest L. Turos, który jako jedyny podjął się zadania, by w dokładny i szczegółowy sposób wniknąć w te funkcje turystyki ${ }^{23}$. To właśnie L. Turos w swoich licznych badaniach i opracowaniach dotyczących młodzieży starał się m.in. ukazać, jak ważnym elementem w procesie autokreacji poprzez samokształcenie, samodoskonalenie, poznawanie siebie i transgresję zajmuje uprawianie turystyki. Autokreacja to według tego uczonego proces doskonalenia własnej osobowości i ukierunkowywania swojej drogi życiowej. Wymaga ona przede wszystkim przekonania, że dla człowieka możliwe jest i korzystne dokonywanie zmian swojej osobowości, zbliżanie się do wybranego ideału osobowości, nabywanie głębszego sensu

20 Por. T. Łobożewicz, G. Bieńczyk, Podstawy turystyki, Warszawa 2001, s. 67.

21 Por. L. Turos, Wprowadzenie do wiedzy o turystyce edukacyjnej, dz. cyt., s. 81.

22 K. Lubański, Pedagogiczny potencjat turystyki, Warszawa 2006, s. 159.

23 Por. B. Alejziak, Samowychowanie a turystyka, dz. cyt., s. 40. 
swojej egzystencji. Szczególną rolę w tym procesie odgrywa zdaniem autora uprawianie turystyki. Jak wykazały bowiem prowadzone przez niego wieloletnie badania własne, turystyka kształtuje osobowość, wzbogaca wiedzę i orientację w rzeczywistości, rozwija zdolności poznawcze człowieka oraz zwiększa jego umiejętności kontrolowania swojego rozwoju i zachowania. Związek turystyki z samowychowaniem manifestuje się również w tym, że sytuacje turystyczne w pewnym stopniu kreują potrzebę dostosowania swojej osobowości do wymagań, jakie stawia środowisko i mieszkańcy zwiedzanych rejonów i krajów ${ }^{24}$.

Związek turystyki i samokształcenia polega na tym, że mamy do czynienia z dialektycznym, wzajemnym pobudzaniem się dwóch form ludzkiej aktywności. Uczestnictwo turystyczne rozszerza zainteresowania uczestników wycieczki, ich wiedzę, horyzonty intelektualne, sposoby myślenia o świecie, zachęca do jego penetracji, przyswajania, poznawania i przeżywania ${ }^{25}$.

$\mathrm{Na}$ podstawie analizy wyników badań własnych i cudzych autor stwierdził, że turystyka w procesie samokształcenia pełni następujące funkcje:

1. dostarcza wrażeń, wyobrażeń, spostrzeżeń i pojęć o otaczającym świecie, na podstawie których możliwe staje się ukształtowanie względnie spójnego i sprawdzalnego obrazu rzeczywistości przyrodniczej, kulturowej i ludzkiej;

2. rozbudza potrzebę badania, poznawania i penetrowania świata, potrzebę rozumienia go i racjonalnego w nim działania;

3. wzbogaca poczucie sensu życia dzięki temu, że ukazuje bogactwo, ogrom i złożoność świata przyrody, społeczeństwa i kultury;

4. ukazuje tereny ludzkiej aktywności, w których ujawnia się ludzki geniusz (wytwory cywilizacji naukowej i technicznej);

5. ukazuje urodę świata (doznania estetyczne związane z pięknem ludzi, krajobrazów i zabytków architektury) i wzmacnia uczucia afirmacji życia;

6. umożliwia porównanie własnego kraju, jego gospodarki, kultury i życia społecznego z innymi krajami; budzi potrzebę doskonalenia życia, gospodarki i kultury we własnym kraju;

24 Por. L. Turos, Turystyka $i$ wychowanie, w: Encyklopedia pedagogiczna XXI wieku, t. 6, red. T. Pilch, Warszawa 2007, s. 824.

25 Por. L. Turos, Wprowadzenie do wiedzy o turystyce edukacyjnej, dz. cyt., s. 18. 
7. rozwija potrzebę studiowania opracowań, materiałów naukowych, przewodników, opisów i danych statystycznych, które umożliwiają głębsze poznanie zwiedzanych krajów i zrozumienie specyfiki ich kultury ${ }^{26}$.

Zdaniem L. Turosa, samowychowanie turystyczne daje szansę specyficznego, otwierającego wielkie możliwości samourabiania i kształtowania swojej osobowości. Jego głównymi celami są: 1) dążenie do rozumienia i respektowania humanistycznych norm współżycia społecznego; 2) ograniczenie egoizmu; 3) uspołecznienie; 4) opanowanie umiejętności identyfikacji z celami i żądaniami grupy turystycznej; 5) eliminację lub chociaż ograniczenie nałogów na czas trwania wycieczki (np. picie alkoholu, palenie papierosów); 6) odzyskanie zdolności bycia sobą; 7) nauczenie się przeżywania radości, której źródłem jest szeroko rozumiane doświadczenie turystyczne; 8) uodpornienie się na trudności; 9) dzielność i pogoda ducha $^{27}$.

Możemy w tym miejscu wyróżnić następujące etapy procesu samowychowania przez turystykę: 1) samopoznanie w kontaktach turystycznych; 2) uświadomienie sobie swoich wad i braków; 3) kształtowanie pozytywnych cech osobowości; 4) samoocenę własnego postępowania; 5) stawianie sobie ambitnych zadańn ${ }^{28}$.

Podsumowując, samowychowanie przez turystykę wyraża się w takiej postawie, gdy dana osoba kształtuje podczas wyjazdu turystycznego te cechy, dzięki którym jest bardziej ceniona, szanowana, lubiana i atrakcyjna. Sprawdzianem ujawnienia lub ukształtowania tych cech jest stosunek do niej pozostałych uczestników grupy turystycznej. Popularność danej osoby w grupie potwierdza jej umiejętność integracji, co przejawia się w życzliwym nastawieniu innych do danej osoby. To z kolei staje się dla niej źródłem moralnej satysfakcji i utrwala w niej tendencje do samowychowania ukierunkowanego na humanistyczne wartości ${ }^{29}$.

\footnotetext{
26 Por. tamże, s. 19-20.

27 Por. tamże, s. 146-147.

28 Por. tamże, s. 146-153.

29 Por. tamże, s. 153.
} 


\section{Cel badań}

$\mathrm{Na}$ potrzeby niniejszego opracowania postanowiono zdiagnozować, czy aktywność turystyczna jest dla podkarpackiej młodzieży ze szkół ponadgimnazjalnych źródłem i sposobem doskonalenia samego siebie. Starano się, między innymi, znaleźć odpowiedzi na następujące pytania: czy badana młodzież dostrzega korzyści wynikające $\mathrm{z}$ uprawiania turystyki zarówno dla rozwoju mentalnego, jak i fizycznego swojego organizmu (jeśli tak, to jakie), czy wyjazdy turystyczne wpłynęły na rozwój jej wiedzy i umiejętności, czy turystyka może być sposobem przeciwdziałania złym (dewiacyjnym) zachowaniom, które są spotykane wśród młodzieży w jej codziennym życiu (w czasie wolnym)?

\section{Materiał i metoda badań}

Badaniami objęto młodzież uczęszczającą do różnych typów szkół ponadgimnazjalnych (liceum ogólnokształcące - LO; technikum - T, zasadnicza szkoła zawodowa - ZSZ) z terenu województwa podkarpackiego. Badania przeprowadzono w następujących miastach: 1) miasta do 20 tyś. mieszkańców - Brzozów, Sieniawa, Ropczyce; 2) miasta do 50 tyś. mieszkańców - Jarosław, Sanok, Dębica; 3) miasta do 100 tyś. mieszkańców - Przemyśl, Krosno; 4) miasta do 500 tyś. mieszkańców - Rzeszów. Badania przeprowadzono główne w latach 2010-2011. Łącznie wzięło w nich udzial ponad tysiąc respondentów. Następnie, po weryfikacji kwestionariuszy, do analizy zakwalifikowano kwestionariusze 983 uczniów. W tej liczbie znalazło się 508 kobiet (51,68\%) i 475 mężczyzn (48,32\%).

Wybór tej grupy miał istotne znaczenie dla badania aktywności turystycznej w kontekście procesu wychowania. W okresie adolescencji młodzież w zróżnicowany sposób podchodzi do kwestii znaczenia i możliwości wykorzystania turystyki dla potrzeb kształtowania osobowości. Nie są to jeszcze ludzie dorośli, tak więc wpływ na ich postawy ma ciągle rodzina oraz szkoła. Jednocześnie wykazują potrzeby udowodnienia swojej samodzielności i niezależności, podejmowania aktywności zespołowej oraz sprawdzenia się w nowych sytuacjach. Turystyka staje się przejawem pracy nad sobą, co stanowi istotę samokształcenia i samowychowania. Młodzież posiada już 
pewien „staż turystyczny”, dlatego prezentuje pewne postawy wobec turystyki (autoteliczną, instrumentalną, nieaprobującą).

Metodą badań zastosowaną w niniejszej pracy był sondaż diagnostyczny, natomiast spośród technik badawczych zastosowana została technika ankietowania. Wykorzystano narzędzie badawcze konstrukcji własnej.

Przedstawione $\mathrm{w}$ niniejszym artykule wyniki badań stanowią część zakrojonych na większą skalę badań, mających na celu zdiagnozowanie stanu wykorzystania aktywności turystycznej na potrzeby procesu wychowania wśród młodzieży szkół ponadgimnazjalnych $\mathrm{z}$ terenu Podkarpacia.

\section{Wyniki badań}

W pierwszym etapie badań postanowiono zdiagnozować, jakie korzyści w opinii respondentów niesie za sobą uprawianie przez nich turystyki. Analiza danych zawartych w tabeli 1 wykazała, że bezapelacyjnie najważniejszą korzyścią było poznawanie nowych regionów, miejsc i atrakcji turystycznych, zarówno tych w kraju, jak i za granicą. Na fakt ten wskazało łącznie ponad $80 \%$ ankietowanych. Cieszy, że tak znaczny odsetek badanych już po odbyciu podróży dostrzegł wartość poznawczej strony turystyki i uznał go za korzyść dla siebie. Jednocześnie należy zaznaczyć, że istniała w tym względzie istotna zależność od płci (chi^2=24,925, C=0,111, p=0,002). Znacznie częściej tę zaletę uprawiania turystyki dostrzegały dziewczęta $(90,94 \%)$ niż chłopcy $(80,00 \%)$. Na kolejnych miejscach wśród najwyżej ocenionych korzyści znalazły się dwie inne, które uzyskały podobną liczbę pozytywnych ocen. Dla połowy ankietowanych bardzo ważne okazało się, że podczas wyjazdu turystycznego mogą robić to, na co mają ochotę. Możliwość dobrowolnego wyboru czynności, na które poświęcali swój czas, oraz spontaniczność w zachowaniu zostały uznane za korzyść przez 50,25\% respondentów. Zbliżone zdanie na ten temat miały zarówno dziewczęta (50,39\%), jak i chłopcy (50,11\%). Grupa ponad 30\% respondentów jako korzyść dla siebie oceniła podobny walor turystyki, a więc wykonywanie ulubionych zajęć, którym można poświęcić czas podczas imprezy turystycznej, a bardzo często nie ma na to czasu w życiu codziennym. W tym względzie płeć miała istotne znaczenie $\left(\operatorname{chi}^{\wedge} 2=12,204, \mathrm{C}=0,111, \mathrm{p}=0,002\right)$, bowiem dziewczęta 
znacznie częściej $(34,65 \%)$ niż chłopcy $(25,89 \%)$ dostrzegały tę zaletę turystyki. Ankietowani również wysoko ocenili korzyść, jaką była poprawa kondycji i sprawności fizycznej, będących następstwem udziału w imprezie turystycznej $(50,00 \%)$. W zakresie tego waloru uczestnictwa w turystyce częściej pozytywne stanowisko zajmowali mężczyźni $(52,63 \%)$ niż kobiety $(47,53 \%)$. Ważnymi korzyściami dla respondentów okazały się te wynikające $\mathrm{z}$ przebywania $\mathrm{w}$ grupie. Obie frakcje (kobiety i mężczyźni) w równym stopniu stwierdzały bowiem, że eskapada turystyczna nauczyła ich zarówno współpracy i współdziałania w grupie, jak i odpowiedzialności za współtowarzyszy wyjazdu. Jest to informacja bardzo istotna, bowiem jedną z podstawowych form pracy wychowawczej w czasie wolnym jest działanie grupowe i zespołowe. Cieszy zatem fakt uznania tej formy organizacyjnej przez badanych uczniów za atrakcyjną, a także dostrzeżenia zalet przebywania w zespole realizującym wspólne cele turystyczne. Istotna dla co trzeciego nastolatka z Podkarpacia okazała się możliwość zmiany codziennego otoczenia (30,82\%), a następnie możliwość bezpośredniego kontaktu z odwiedzanym środowiskiem (38,15\%). Te dwie korzyści znacznie częściej dostrzegały kobiety (35,04\% i 40,94\%) niż mężczyźni (26,32\% i 35,16\%). Na koniec wskazać należy jeszcze jedną korzyść wynikającą z uprawiania turystyki, a dostrzeżoną przez liczniejszą grupę mężczyzn (41,56\%) niż kobiet (32,87\%). Podczas wyjazdu turystycznego często musimy podejmować kluczowe i ważne decyzje wynikające z szybko zmieniających się warunków środowiska w których się znajdujemy. Właśnie na tę umiejętność wyniesioną z uczestnictwa w imprezach turystycznych wskazywała męska część respondentów.

\begin{tabular}{|l|c|c|c|c|c|c|}
\hline \multirow{2}{*}{$\begin{array}{c}\text { Korzyści odniesione } \\
\text { z uprawiania turystyki* }\end{array}$} & \multicolumn{5}{|c|}{ Płeć } \\
\cline { 2 - 5 } & Kobiety & Mężczyźni & Razem & \multirow{2}{*}{ Ch^2 $^{\wedge}$} & C & P \\
\cline { 2 - 6 } $\begin{array}{l}\text { Mogłem zmienić } \\
\text { środowisko mojego } \\
\text { życia }\end{array}$ & 35,04 & 26,32 & 30,82 & 12,082 & 0,111 & 0,002 \\
\hline $\begin{array}{l}\text { Poznałem nowe regiony, } \\
\text { miejsca }\end{array}$ & 90,94 & 80,00 & 85,66 & 24,925 & 0,159 & 0,000 \\
\hline $\begin{array}{l}\text { Mogłem wykonywać } \\
\text { moje ulubione zajęcia }\end{array}$ & 34,65 & 25,89 & 30,42 & 12,204 & 0,111 & 0,002 \\
\hline $\begin{array}{l}\text { Mogłem robić to, na co } \\
\text { mam ochotę }\end{array}$ & 50,39 & 50,11 & 50,25 & 3,954 & 0,063 & 0,138 \\
\hline
\end{tabular}

Tabela 1.

Korzyści z uprawiania turystyki w opinii badanych a płeć 


\begin{tabular}{|c|c|c|c|c|c|c|}
\hline \multirow{3}{*}{$\begin{array}{l}\text { Korzyści odniesione } \\
\text { z uprawiania turystyki* }\end{array}$} & \multicolumn{6}{|c|}{ Płeć } \\
\hline & Kobiety & Mężczyźni & Razem & $\mathrm{Cb} \wedge$ ? & $c$ & p \\
\hline & $\%$ & $\%$ & $\%$ & $\ln 2$ & $c$ & $r$ \\
\hline $\begin{array}{l}\text { Miałem bezpośredni } \\
\text { kontakt z odwiedzanym } \\
\text { środowiskiem }\end{array}$ & 40,94 & 35,16 & 38,15 & 6,969 & 0,084 & 0,030 \\
\hline $\begin{array}{l}\text { Umiem szybko } \\
\text { reagować na zmienne } \\
\text { warunki w terenie, na } \\
\text { nowe sytuacje }\end{array}$ & 17,13 & 27,00 & 21,89 & 18,656 & 0,138 & 0,001 \\
\hline $\begin{array}{l}\text { Sam podejmuję } \\
\text { ważne decyzje }\end{array}$ & 32,87 & 41,56 & 37,07 & 12,674 & 0,114 & 0,002 \\
\hline $\begin{array}{l}\text { Nauczyłem się } \\
\text { odpowiedzialności za } \\
\text { siebie i całą grupę }\end{array}$ & 37,60 & 36,21 & 36,93 & 4,052 & 0,642 & 0,132 \\
\hline $\begin{array}{l}\text { Nauczyłem się } \\
\text { współpracy } \\
\text { i współdziałania } \\
\text { w grupie }\end{array}$ & 43,90 & 43,16 & 43,54 & 3,955 & 0,063 & 0,138 \\
\hline $\begin{array}{l}\text { Nauczyłem się } \\
\text { szanować poglady } \\
\text { innych, ale jednocześnie } \\
\text { potrafię bronić swoich }\end{array}$ & 29,13 & 28,42 & 28,79 & 3,967 & 0,064 & 0,138 \\
\hline $\begin{array}{l}\text { Poprawiłem swoiq } \\
\text { kondycię i sprawność } \\
\text { fizycznq }\end{array}$ & 47,53 & 52,63 & 50,00 & 7,074 & 0,085 & 0,029 \\
\hline Odniosłem inne korzyści & 2,56 & 3,16 & 2,85 & - & - & - \\
\hline
\end{tabular}

*0,71\% badanych nie odpowiedziało na to pytanie Źródło: opracowanie własne

Jak już pisano powyżej, jedną z dowiedzionych zalet uprawnia turystyki jest możliwość kształtowania własnej osobowości. Kształtowanie osobowości, samopoznanie, samoocena, aspiracje perfekcjonistyczne, decyzje samorealizacyjne, a także działania samowychowawcze idą $\mathrm{w}$ parze $\mathrm{z}$ uprawianiem turystyki. Dlatego też zapytano młodzież, czy jej zdaniem wyjazd turystyczny daje możliwość doskonalenia samego siebie. Uzyskane wyniki (tabela 2) pokazują, że badani dostrzegają taką zaletę aktywności turystycznej. Zdecydowana większość, bo aż 3/4 respondentów odpowiedziało pozytywnie na to pytanie, stwierdzając, że wyjazd poza miejsce stałego zamieszkania sprzyja kształtowaniu i doskonaleniu własnej osobowości. 


\begin{tabular}{|c|c|c|c|c|c|c|}
\hline \multirow{3}{*}{$\begin{array}{c}\text { Doskonalenie } \\
\text { samego siebie* }\end{array}$} & \multicolumn{6}{|c|}{ Płeć } \\
\hline & \multicolumn{2}{|c|}{ Kobiety } & \multicolumn{2}{|c|}{ Mężczyźni } & \multicolumn{2}{|c|}{ Razem } \\
\hline & $\mathbf{N}$ & $\%$ & $\mathbf{N}$ & $\%$ & $\mathbf{N}$ & $\%$ \\
\hline Tak & & 80,12 & & 71,16 & & 75,79 \\
\hline Nie & & 19,88 & & 28,42 & & 24,01 \\
\hline
\end{tabular}

*0,20\% badanych nie odpowiedziało na to pytanie Źródło: opracowanie własne

Uzupełnieniem powyższego było otwarte pytanie: „W jaki sposób wyjazd turystyczny sprzyja doskonaleniu samego siebie?" Odpowiedziało na nie łącznie $60,43 \%$ badanych. Na podstawie wypowiedzi respondentów możemy stwierdzić, że najczęściej dostrzeganą przez nich korzyścią wpływającą na rozwój osobowości jest zdobycie nowych umiejętności. Trzeba zaznaczyć, że dla młodych wyjazd turystyczny daje możliwość nauki nowych czynności z bardzo różnych zakresów. $Z$ jednej strony są to czynności bezpośrednio związane $z$ turystyką, takie jak posługiwanie się odpowiednim sprzętem, sprawne poruszanie się w trudnym terenie czy radzenie sobie w nowym otoczeniu i środowisku. Innego typu umiejętności, które można zdobyć dzięki wyjazdowi turystycznemu, to zdaniem respondentów na przykład nauka języka obcego. Jeszcze innym czynnikiem wpływającym na rozwój osobowy jednostki okazała się możliwość sprawdzenia siebie w trudnych sytuacjach. Młodzi stwierdzali, że wyjazd turystyczny pozwolił im sprawdzić swoje umiejętności i zdolności, a z drugiej strony spowodował, że dostrzegali własne słabości i lęki. Fakt ten zdaniem badanych był istotny w kontekście kształtowania własnej osobowości. Podobna liczba ankietowanych stwierdziła, że dzięki uczestnictwu w turystyce nauczyła się samodzielności i odpowiedzialności za siebie i pozostałych współtowarzyszy eskapady. Na podstawie tych wypowiedzi możemy zatem uznać, że aktywność turystyczna ma istotny wpływ na samokontrolę oraz samodyscyplinę, co jest bardzo ważną korzyścią płynącą z takiej formy spędzania czasu wolnego. Według badanych adolescentów innymi czynnikami wpływającymi na doskonalenie samego siebie były: możliwość dostrzeżenia własnych wad w nowym otoczeniu, a przez to rozwój kultury osobistej; zdobycie doświadczenia życiowego; nauka
Tabela 2.

Opinia na temat możliwości doskonalenia samego siebie podczas wyjazdu turystycznego a pleć badanych 
tolerancji dla innych, dla ich poglądów, kultury, obyczajów. Poza tym młodzi dostrzegają również korzyści związane $\mathrm{z}$ rozwojem fizycznym swojego organizmu. Stwierdzali bowiem, że udział w imprezie turystycznej pozwala na podniesienie sprawności i kondycji fizycznej organizmu.

Wszystkie wypowiedzi badanych na pytanie „W jaki sposób wyjazd sprzyja doskonaleniu samego siebie" obrazuje poniższe zestawienie, pokazujące najczęściej pojawiające się odpowiedzi:

1. Zdobycie nowych umiejętności - 15,87\%;

2. Możliwość sprawdzenia samego siebie, swoich umiejętności (odkrycie własnych fantazji, lęków, słabości w trudnych sytuacjach) $12,11 \%$

3. Nauka samodzielności, odpowiedzialności-11,90\%;

4. Rozwój kultury osobistej (poprzez dostrzeganie własnych wad w innym otoczeniu): $-6,92 \%$;

5. Podniesienie kondycji fizycznej i psychicznej-3,56\%;

6. Zdobycie doświadczenia życiowego - 3,15\%;

7. Rozwijanie zainteresowań $-1,93 \%$;

8. Dzięki podróżom patrzę inaczej na świat - $1,73 \%$;

9. Stałem się bardziej otwarty na innych $-1,22 \%$;

10. Nauka tolerancji dla innych kultur - 1,02\%;

11. Nauka współżycia w grupie - $1,02 \%$.

Jak wynika z powyższej analizy, najważniejszym czynnikiem wpływającym na rozwój osobowości w trakcie uprawiania turystyki jest możliwość zdobycia nowych umiejętności, dlatego też w dalszej części badań zapytano młodzież jakie nowe umiejętności zdobyła $\mathrm{w}$ trakcie eskapady turystycznej. $Z$ badań zaprezentowanych w tabeli 3 wynika, że największa liczba respondentów wyniosła z podróży turystycznej umiejętności: racjonalnego dysponowania środkami finansowymi $(67,86 \%)$, orientacji w terenie $(66,22 \%)$ oraz planowania i robienia zakupów $(60,02 \%)$. Poza tym praktycznie co drugi z badanych nastolatków wskazywał na nabycie takich umiejętności, jak: przygotowywanie posiłków $(51,17 \%)$, sprzątanie kwatery $(49,84 \%)$ a także pranie własnej odzieży $(45,27 \%)$. Inne, jak umiejętność posługiwania się sprzętem turystycznym $(39,26 \%)$, przygotowywanie i opis tras turystycznych $(27,46 \%)$ oraz udzielanie pierwszej pomocy przedmedycznej $(24,64 \%)$ nabyte zostały przez nieco mniejszą grupę badanych. 
Uogólniając, wyniki badań dotyczące nabywania przez młodzież nowych umiejętności podczas wyjazdów poza miejsce stałego zamieszkania należy uznać za zadowalające. Dzięki uprawianiu turystyki młodzież staje się bardziej samodzielna, potrafi dysponować środkami finansowymi czy też umie zaplanować i zrobić racjonalne zakupy. Udoskonala również zdolności samoobsługowe, takie jak pranie własnej odzieży, sprzątanie zamieszkiwanej kwatery oraz przygotowywanie posiłków. Są to jakże ważne czynności dnia powszedniego, niezbędne do funkcjonowania w dorosłym świecie. Dobrze wypada również przyswajanie umiejętności typowo turystycznych, jak orientacja $\mathrm{w}$ terenie oraz posługiwanie się sprzętem turystycznym.

\begin{tabular}{|l|c|c|c|c|c|c|}
\hline \multirow{2}{*}{\multicolumn{1}{|c|}{ Umiejętności* }} & \multicolumn{5}{|c|}{ Płeć } \\
\cline { 2 - 7 } & \multicolumn{2}{|c|}{ Kobiety } & \multicolumn{2}{|c|}{ Mężczyźni } & \multicolumn{2}{c|}{ Razem } \\
\cline { 2 - 7 } & N & $\%$ & N & $\%$ & N & $\%$ \\
\hline $\begin{array}{l}\text { Posługiwanie się } \\
\text { sprzętem turystycznym }\end{array}$ & 175 & 34,45 & 211 & 44,42 & 386 & 39,26 \\
\hline $\begin{array}{l}\text { Przygotowanie i opis } \\
\text { tras turystycznych }\end{array}$ & 100 & 19,68 & 170 & 35,79 & 270 & 27,46 \\
\hline Orientacja w terenie & 326 & 64,17 & 325 & 68,42 & 651 & 66,22 \\
\hline $\begin{array}{l}\text { Przygotowywanie } \\
\text { posiłków }\end{array}$ & 287 & 56,50 & 216 & 45,48 & 503 & 51,17 \\
\hline $\begin{array}{l}\text { Planowanie i robienie } \\
\text { zakupów }\end{array}$ & 331 & 65,16 & 259 & 54,53 & 590 & 60,02 \\
\hline $\begin{array}{l}\text { Racjonalne } \\
\text { dysponowanie } \\
\text { środkami finansowymi }\end{array}$ & 362 & 71,26 & 305 & 64,21 & 667 & 67,86 \\
\hline Sprzq̨anie kwatery & 272 & 53,54 & 218 & 45,89 & 490 & 49,84 \\
\hline $\begin{array}{l}\text { Pranie własnej } \\
\text { odzieży }\end{array}$ & 257 & 50,59 & 188 & 39,58 & 445 & 45,27 \\
\hline $\begin{array}{l}\text { Udzielanie } \\
\text { pierwszej pomocy } \\
\text { przedmedycznej }\end{array}$ & 107 & 21,06 & 135 & 28,48 & 242 & 24,64 \\
\hline \begin{tabular}{l} 
Inne umiejętności \\
\hline$y y y y y y$
\end{tabular} & 0,20 & 4 & 0,84 & 5 & 0,51 \\
\hline
\end{tabular}

Tabela 3.

Zdobycie

nowych umieiętności

podczas wyjazdu

a płeć

(dane w \%)

*nie wszyscy badani odpowiedzieli na to pytanie

Źródło: opracowanie własne 
W dalszym etapie badań postanowiono zdiagnozować, czy turystyka może być sposobem przeciwdziałania złym (a nawet dewiacyjnym) zachowaniom. W tym celu zadano młodzieży pytanie, jakie negatywne zachowania zdarzają im się w czasie wolnym, a jakie podczas wyjazdu turystycznego. $\mathrm{W}$ poniższej tabeli $\mathrm{nr} 4$ przedstawiono porównanie uogólnionych wyników badań dotyczących złych zachowań respondentów, zdarzających się w czasie wolnym, z tymi samymi zachowaniami, ale mającymi miejsce podczas wyjazdu turystycznego. Jak możemy zaobserwować, wśród badanej populacji negatywne zachowania częściej występują w krótkim i średnim czasie wolnym niż w trakcie eskapady poza miejsce stałego zamieszkania. Natomiast w kilku przypadkach jest to różnica dość znaczna. Jeśli porównamy np. spożywanie alkoholu w czasie wolnym i podczas wyjazdu turystycznego, to zauważyć możemy, że w pierwszym przypadku sięganie po używki zadeklarowało łącznie $65,41 \%$ ankietowanych, natomiast w przypadku drugim 49,64\%. Widoczna jest zatem dość znaczna różnica dowodząca, że młodzi mieszkańcy Podkarpacia częściej piją alkohol w swoim środowisku lokalnym, niż w czasie podróży. Podobnie jest w przypadku uprawiania seksu (czas wolny 30,92\%, wyjazd turystyczny 18,00\%) oraz wdawania się w bójki (czas wolny 22,18\%, wyjazd turystyczny 15,87\%) - tu również widoczna jest znaczna różnica w złych zachowaniach na „niekorzyść” czasu wolnego. W przypadku pozostałych zachowań niebezpiecznych (m.in. zażywania narkotyków, palenia papierosów itp.) odsetek respondentów, którym się one przytrafiają jest bardzo zbliżony w obu przypadkach. Możemy zatem założyć, że te same osoby, które np. palą papierosy w czasie wolnym, robią to również podczas imprezy turystycznej.

\begin{tabular}{|c|c|c|c|c|c|c|c|}
\hline \multirow{7}{*}{$\begin{array}{r}\text { Tabela } 4 . \\
\text { Zachowania niebez- } \\
\text { pieczne w czasie } \\
\text { wolnym młodzieży } \\
\text { a zachowania } \\
\text { niebezpieczne i de- } \\
\text { wiacyjne podczas } \\
\text { wyjazdu turystycz- } \\
\text { nego (dane w \%) }\end{array}$} & \multirow{3}{*}{ Zachowania dewiacyjne } & \multicolumn{6}{|c|}{ Czas wolny a wyjazd turystyczny } \\
\hline & & \multicolumn{3}{|c|}{ Czas wolny } & \multicolumn{3}{|c|}{ Wyjazd furystyczny } \\
\hline & & często & rzadko & wcale & często & rzadko & wcale \\
\hline & Picie alkoholu & 15,46 & 49,95 & 34,59 & 20,96 & 28,18 & 50,36 \\
\hline & Zażywanie narkotyków & 1,53 & 5,09 & 93,39 & 2,14 & 3,87 & 93,49 \\
\hline & Palenie papierosów & 12,41 & 14,34 & 73,25 & 11,09 & 13,53 & 74,88 \\
\hline & $\begin{array}{l}\text { Naruszanie norm moral- } \\
\text { nych (kradzieże) }\end{array}$ & 1,12 & 6,82 & 92,07 & 1,83 & 4,58 & 93,09 \\
\hline
\end{tabular}




\begin{tabular}{|l|r|r|r|r|r|r|}
\hline \multirow{2}{*}{ Zachowania dewiacyine } & \multicolumn{5}{|c|}{ Czas wolny a wyjazd turystyczny } \\
\cline { 2 - 7 } & \multicolumn{3}{|c|}{ Czas wolny } & \multicolumn{3}{c|}{ Wyjazd turystyczny } \\
\cline { 2 - 7 } & często & rzadko & wcale & często & rzadko & wcale \\
\hline Bójki & 2,75 & 19,43 & 77,82 & 3,36 & 11,60 & 84,13 \\
\hline Uprawianie seksu & 10,17 & 20,75 & 69,07 & 6,41 & 11,09 & 82,00 \\
\hline Kontakt z sektami & 1,42 & 1,93 & 96,64 & 1,12 & 1,73 & 96,65 \\
\hline
\end{tabular}

Źródło: opracowanie własne

$\mathrm{Na}$ podstawie powyższego zestawienia możemy postawić wniosek, że aktywność turystyczna młodzieży ma pozytywny wpływ na ich zachowanie. Badania dowiodły, że w przypadku wszystkich wymienionych zachowań o treści niebezpiecznej częstotliwość ich występowania wśród respondentów jest niższa w trakcie wyjazdu turystycznego w porównaniu z krótkim i średnim czasem wolnym. Młodzież pozostawiona na co dzień z problemem odpowiedniego zagospodarowania czasu wolnego dość często ucieka do zachowań niebezpiecznych, niosących za sobą ryzyko uzależnienia, utraty zdrowia czy też wejścia w konflikt z prawem. Podczas wyjazdu turystycznego, gdy czas jest odpowiednio zagospodarowany, widoczny jest spadek liczby takich zachowań. Nie oznacza to oczywiście, że podczas imprezy turystycznej młodzież nie sięga po alkohol, papierosy oraz nie zachowuje się nieodpowiednio pod innymi względami. Jednak badania dowiodły, że liczba złych zachowań spada podczas uprawiania turystyki, co jest bardzo optymistyczne.

Aby zweryfikować ten pogląd, zapytano samych zainteresowanych, co sądzą na temat możliwości przeciwdziałania złym zachowaniom poprzez uprawianie turystyki. Jak możemy zauważyć, 18,31\% ogólu respondentów dostrzega taką zaletę turystyki (tabela 5). Dla tej grupy ankietowanych wyjazd turystyczny stanowi pewną alternatywę dla codziennych zachowań wolnoczasowych, nie zawsze pozytywnych. Zaznaczyć trzeba, że zarówno kobiety, jak i mężczyźni mają podobne zdanie na ten temat. 


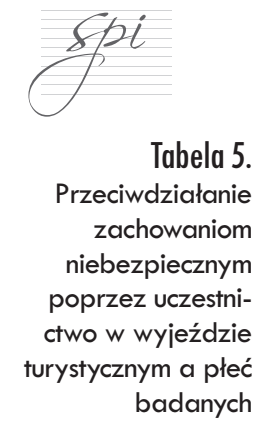

\begin{tabular}{|c|c|c|c|c|c|c|}
\hline \multirow{2}{*}{$\begin{array}{c}\text { Turystyka a możliwość } \\
\text { przeciwdziałania złym } \\
\text { zachowaniom }\end{array}$} & \multicolumn{2}{|c|}{ Kobiety } & \multicolumn{2}{|c|}{ Mężczyźni } & \multicolumn{2}{c|}{ Razem } \\
\cline { 2 - 7 } & $\mathbf{N}$ & $\%$ & $\mathbf{N}$ & $\%$ & $\mathbf{N}$ & $\%$ \\
\hline Tak & 98 & 19,29 & 82 & 17,26 & 180 & 18,31 \\
\hline Nie & 410 & 80,71 & 391 & 82,32 & 801 & 81,49 \\
\hline
\end{tabular}

*0,20\% badanych nie odpowiedziało na to pytanie Źródło: opracowanie własne

W toku dalszych badań poproszono respondentów, którzy udzielili pozytywnej odpowiedzi, o komentarz i wyjaśnienie swojego zdania. Do grupy najczęściej pojawiających się uzasadnień pozytywnego stanowiska wobec możliwości przeciwdziałania zachowaniom niebezpiecznym poprzez uprawianie turystyki można zaliczyć następujące odpowiedzi: 1) uczymy się współżycia w grupie, przestrzegamy zasad grupy - 3,36\%;2) wyjazd skłania do refleksji nad sobą - 2,54\%; 3) poprzez odkrycie piękna świata i przyrody człowiek odkrywa dobro w sobie - 2,54\%; 4) wyjazd wymusza na nas racjonalne myślenie i odpowiedzialność; musimy się kontrolować, by nie doszło do wypadku 2,44\%; 5) poprzez zmagania z samym sobą i innymi trudnościami nie mamy czasu na złe zachowania; jest okazja, by wyładować się w inny sposób - 2,03\%; 6) w czasie wyjazdu zorganizowanego trzeba dostosować się do reguł ustalonych przez opiekuna $-1,93 \%$; 7) poprzez zmianę otoczenia możemy uniknąć złego towarzystwa, złych zachowań z podwórka - 1,83\%; 8) jest to uzależnione od programu imprezy (jeśli program jest atrakcyjny, to możemy przeciwdziałać,jeśli jest mało atrakcyjny i mamy za dużo czasu wolnego, to nie $-1,32 \%$; 9) złe zachowania są wynikiem niezorganizowanego czasu wolnego, natomiast wyjazd turystyczny przeciwdziała nudzie i głupim pomysłom - 1,29\%; 10) to zależy od towarzystwa z jakim wyjeżdżamy $-0,81 \%$.

\section{Wnioski}

Przeprowadzona analiza wykazała, że młodzież dostrzega korzyści wynikające z uprawiania turystyki zarówno dla rozwoju mentalnego, jak i fizycznego swojego organizmu. Respondenci wskazywali na korzyści poznawcze, edukacyjne, emocjonalne, aktywnościowe, 
katartyczne i społeczne, jakie daje im aktywność turystyczna. Młodzi stwierdzali również, że wyjazd turystyczny miał pozytywny wpływ na kształtowanie ich osobowości. Najczęściej dostrzeganą przez nich korzyścią wpływającą na rozwój osobowości było zdobycie nowych umiejętności. Były to czynności bezpośrednio związane z turystyką, takie jak posługiwanie się odpowiednim sprzętem, sprawne poruszanie się $\mathrm{w}$ trudnym terenie czy radzenie sobie w nowym otoczeniu i środowisku, ale także inne zdolności, jak choćby nauka obcego języka. Respondenci zaznaczali, że wyjazd turystyczny pozwolił sprawdzić im swoje dotychczasowe umiejętności i zdolności, a z drugiej strony spowodował, że dostrzegali swoje słabości i lęki. Wpłynął pozytywnie na kształtowanie samodzielności i odpowiedzialności za siebie i pozostałych współtowarzyszy eskapady, a więc miał istotny wpływ na samokontrolę oraz samodyscyplinę. Inne czynniki wpływające na doskonalenie samego siebie, to według badanych adolescentów możliwość dostrzeżenia własnych wad w nowym otoczeniu, a przez to rozwój kultury osobistej; zdobycie doświadczenia życiowego; nauka tolerancji dla innych, dla ich poglądów, kultury, obyczajów. Poza tym młodzi dostrzegają również korzyści związane z fizycznym rozwojem swojego organizmu. Stwierdzali bowiem, że udział w imprezie turystycznej pozwala na podniesienie sprawności i kondycji fizycznej.

Bardzo pozytywnie wypadła próba zdiagnozowania możliwości przeciwdziałania złym zachowaniom młodzieży poprzez uprawianie turystyki. Powszechnie przyjmuje się, że wyjazdy turystyczne są miejscem luźnych i nie zawsze pozytywnych zachowań. Starano się zatem zbadać, czy wyjazd turystyczny jest miejscem propagowania zachowań niebezpiecznych i dewiacyjnych czy wręcz przeciwnie. Porównanie zachowań młodzieży w czasie wolnym i podczas wyjazdu poza miejsce stałego zamieszkania wykazało rzadsze występowaniem zachowań o treści niebezpiecznej podczas trwania imprezy turystycznej. Można zatem wysnuć wniosek, że aktywność turystyczna stanowi alternatywę dla zachowań patologicznych występujących w czasie wolnym. Jej uprawianie może być z jednej strony dobrą metodą profilaktyki złych zachowań, a z drugiej - metodą kształtowania odpowiednich, akceptowanych społecznie wzorów zachowań prowadzących do socjalizacji młodzieży. Co ciekawe, tę zaletę uprawiania turystyki dostrzegł prawie co trzeci z badanych nastolatków. Ta grupa respondentów uznała wręcz turystykę za antidotum na zachowania 
dewiacyjne pojawiające się w tradycyjnym czasie wolnym. Nie oznacza to, że wyjazdy turystyczne były wolne od złych zachowań. Oczywiście wśród badanych nastolatków z Podkarpacia, którzy uprawiają turystykę, takie zachowania występowały dość często. Jednak jak sami zainteresowani wskazywali, ich występowanie uzależnione było od wielu czynników, z których najważniejszymi wydają się być: 1) atrakcyjność programu imprezy (bądź też nieatrakcyjność); 2) towarzystwo innych osób uczestniczących we wspólnym wyjeździe; 3) postawy uczestników wyjazdu.

Podsumowując całość wyników badań przedstawionych w niniejszym artykule, możemy stwierdzić, że dla dużej grupy badanych aktywność turystyczna przyczyniała się do stawiania sobie samym wysokich wymagań związanych z kształtowaniem własnej osobowości (zaspokojenia potrzeby samodoskonalenia, samodyscypliny, samokontroli). Znaczna część młodzieży biorącej udział w wyjeździe turystycznym wykazuje potrzebę przyjęcia na siebie odpowiedzialności za kierowanie własnym rozwojem i staje się podmiotem procesu samowychowania. Różnorodne formy aktywności turystycznej sprzyjają kształtowaniu się jej osobistego systemu aksjologicznego. Młodzież ta rozwija w sobie zainteresowania i umiejętności kierowania własnym rozwojem. Dostrzega także w aktywności turystycznej możliwości skutecznego przeciwdziałania zachowaniom szkodliwym, a nawet dewiacyjnym. Wyniki powyższych badań pozwalają stwierdzić, że odpowiednio programowana i uprawiana turystyka może stanowić antidotum na obecne problemy wychowawcze młodego pokolenia.

\section{Bibliografia}

Alejziak B., Samowychowanie a turystyka, Albis, Kraków 2003.

Denek K., Wartości jako źródto edukacji, w: Dziecko w świecie wartości, t. 1, red. K. Denek i in., Oficyna Wydawnicza „Impuls”, Kraków 2003, s. 19-40.

Dudzikowa M., Praca mtodzieży nad sobq. Z teorii i praktyki, Wydawnictwo Terra, Warszawa 1993.

Dziewiecki M., Osoba i wychowanie. Pedagogika personalistyczna w praktyce, Wydawnictwo Rubikon, Kraków 2003.

Kaja B., Wspomaganie rozwoju, czyli „dobrze jest mieć przyjaciót we wszystkich okolicznościach życia", w: Wspomaganie rozwoju. Psychostymulacja i psychokorekcja, t. 6, red. B. Kaja, Wydawnictwo Uczelniane WSP, Bydgoszcz 2004, s. 11-25. 
Kielar-Turska M., Analiza pola semantycznego terminów zwiq̨anych ze wspomaganiem rozwoju, w: Wspomaganie rozwoju. Psychostymulacja i psychokorekcja, t. 5, red. B. Kaja, Wydawnictwo Uczelniane WSP, Bydgoszcz 2003, s. 11-24.

Kulas H., Samoocena mtodzieży, Wydawnictwa Szkolne i Pedagogiczne, Warszawa 1986.

Lubański K., Pedagogiczny potencjat turystyki, AlmaMer. Wyższa Szkoła Ekonomiczna, Warszawa 2006.

Łobocki M., ABC wychowania, Wydawnictwo UMCS, Lublin 2003.

Łobożewicz T., Bieńczyk G., Podstawy turystyki, Wyższa Szkoła Ekonomiczna, Warszawa 2001.

Nowak M., Personalistyczne wychowanie, w: Encyklopedia pedagogiczna XXI wieku, t. 4, red. T. Pilch, Wydawnictwo Akademickie „Żak”, Warszawa 2005, s. 353-358.

Pietrasiński Z., Kierowanie wtasnym rozwojem, Iskry, Warszawa 1977.

Pięta J., Pedagogika czasu wolnego, Wyższa Szkoła Ekonomiczna, Warszawa 2004.

Ratusiowa A., Autokreacja charakterologiczna, w: Encyklopedia pedagogiczna XXI wieku, t. 1, red. T. Pilch, Wydawnictwo Akademickie „Żak”, Warszawa 2003, s. 240-243.

Turos L., Wprowadzenie do wiedzy o turystyce edukacyjnej, wyd. 2. rozszerzone, Ypsylon, Warszawa 2001.

Turos L., Turystyka i wychowanie, w: Encyklopedia pedagogiczna XXI wieku, t. 6, red. T. Pilch, Wydawnictwo Akademickie „Żak”, Warszawa 2007, s. 822-828.

Wysocka E., Doświadczanie życia w mtodości - problemy, kryzysy i strategie ich rozwiazywwania. Próba opisu strukturalno-funkcjonalnego modelu życia preferowanego przez mtodzież z perspektywy pedagogiki spotecznej, Wydawnictwo UŚ, Katowice 2010.

\section{ADRES DO KORESPONDENCJI:}

Dr Marcin Warchoła

Państwowa Wyższa Szkoła Techniczno-Ekonomiczna

im. ks. B. Markiewicza w Jarosławiu

Instytut Stosunków Międzynarodowych

Zakład Turystyki i Rekreacji

marcin.warchola@pwste.edu.pl 